\title{
Порушення функції контралатеральної нирки при обтурувальних пухлинних тромбах інтерренального сегмента нижньої порожнистої вени
}

\author{
V. I. RUSYN, V. V. KORSAK, A. V. RUSYN, S. O. BOIKO \\ SHEI "Uzhhorod National University"
THE DYSFUNCTION OF THE CONTRLATERAL KIDNEY ATTACHED TO OCCLUSIVE TUMOR THROMBUS IN INTERRENAL SEGMENT OF THE INFERIOR VENA CAVA

\begin{abstract}
У роботі представлено 4 випадки нирково-клітинного раку, ускладненого обтурувальними пухлинними тромбами інтерренального сегмента нижньої порожнистої вени. За допомогою динамічної реносцинтиграфії у всіх випадках було виявлено більш значне порушення функції здорової нирки, ніж ураженої пухлиною. Сдиним методом лікування даного контингенту хворих с оперативний.
\end{abstract}

Four cases of renal cell carcinoma that's complicated by occlusive tumor thrombus in interrenal segment of the inferior vena cava are adduced. Significantly more dysfunction of the healthy kidney than affected by tumor was found in all cases by dynamic renoscintigraphy. Operative treatment is the only for this group of patients.

Постановка проблеми і аналіз останніх досліджень та публікацій.Нирково-клітинний рак (НКР) складає близько 90-95 \% усіх гістологічних форм пухлин нирки [4]. В Україні у 2011 році рівень захворюваності на НКР становив 11,5 на 100 тис. населення, причому в 5 тис. 245 осіб було вперше зареєстровано випадки захворювань нирки, з яких I-II стадію мали 50,8 \%, III стадію - 24,8 \% i IV стадію - 20,8 \% [1]. I дотепер “золотим стандартом" хірургічного лікування НКР залишається радикальна нефректомія.

Для хірурга, який планує видалити нирку, важливим моментом $\epsilon$ володіння інформацією про те, чи є у пацієнта друга нирка та який іï функціональний стан. 3' ясування функціонального стану нирок при місцево-розповсюдженому НКР, ускладненому венозною інвазією, має надзвичайно важливе значення, оскільки тактика лікування даних пацієнтів заздалегідь передбачає нефректомію та тромбектомію, при якій штучно створюються умови тимчасового порушення кровотоку в контралатеральній нирці, що, в свою чергу, відображається на її функціональному стані. Ці обставини спонукають до дуже ретельного вивчення функціонального стану нирок у хворих на НКР, ускладнений венозною інвазією, на діагностичному етапі, щоб попередити можливий стрімкий розвиток ниркової недостатності в післяопераційному періоді.
Мета роботи: визначити особливості функціонального стану контралатеральної нирки при нирково-клітинному раку, ускладненому венозною інвазією.

Матеріали і методи. У дослідження включено 4 хворих на нирково-клітинний рак, ускладнений венозним тромбозом. Усі пацієнти чоловіки, віком від 54 до 73 років. Діагностичний алгоритм складався із клінічних, лабораторних, променевих та гістологічних методів, прийнятих в онкоурології.

Функціональний стан нирок визначали за допомогою радіоізотопної реносцинтиграфії та динамічної нефросцинтиграфії, а також за рівнем роздільної і сумарної швидкості клубочкової фільтрації (ШКФ). Для дослідження використовували гломерулотропний радіоактивний ізотоп технецію (Tc-99m-DTPA), який вводили внутрішньовенно із розрахованої активності об'ємом 0,3-0,5 мл. Тривалість дослідження становила 20-30 хв, збір інформації проводили з експозицією 1 кадр за 1 хв. Датчики розташовували над кожною ниркою та над серцем. За результатами комп'ютерного опрацювання отримували криві із зони інтересу: серцева крива, правої та лівої нирки. Детальному аналізу піддавали сегменти кривих кожної нирки, отриманих на радіоізотопних ренограмах.

Поширення пухлинного тромбу в нижній порожнистій вені (НПВ) оцінювали за 5 рівнями розпов- 
сюдження згідно з класифікацією клініки Меуо [3]. Так, II рівень венозного поширення пухлинного тромбу виявлено у 2 пацієнтів, III рівень - у 2.

Усі пацієнти мали світлоклітинний НКР у стадії $\mathrm{T}_{3} \mathrm{~N}_{0} \mathrm{M}_{0}$, ускладнений пухлинною венозною інвазісю.

Усім хворим проведено хірургічне лікування: радикальну нефректомію, тромбектомію, яка у всіх випадках завершена неповною апаратною каваплікацією. Радикальна нефректомія з тромбектомією із НПВ виконана з трансабдомінального двобічного підребрового доступу в модифікації за типом "Chevron".

Результати досліджень та їх обговорення. У всіх хворих після проведення реносцинтиграфії було виявлено значне порушення функції здорової нирки, яке чітко фіксували на кривих ренограм та на кількісних характеристиках роздільної ШКФ нирок. Ізостенуричний тип кривої був характерним для всіх випадків на боці ураженої пухлиною нирки ускладненою венозною інвазією. Крім того, ми спостерігали більш виражений ізостенуричний тип кривої на боці здорової нирки, при якому сама амплітуда кривої була майже в 2 рази нижчою, ніж на стороні ураженої пухлиною нирки. На нашу думку, причиною більш виражених порушень функції не ураженої пухлиною нирки могло бути явище недостатності венозного відтоку внаслідок значного розповсюдження венозного тромбу і створення механічної перешкоди відтоку крові при недостатності відкриття можливих колатералей, яке призвело до розвитку прогресуючої дисфункції здорової нирки за рахунок зниження її перфузії і функціонального стану.

Зниження ШКФ ураженої чи обох нирок виявлено у всіх хворих, причому зниження відбувалося більше ніж на $50 \%$ від нормального рівня, що не було діагностовано іншими методами обстеження. Середні значення ШКФ здорової нирки були нижчими, ніж ураженої пухлиною нирки $((18,4 \pm 6,2)$ i $(22,7 \pm 8,3)$ мл/хв відповідно).

Беручи до уваги той факт, що єдиним методом лікування даного контингенту хворих є оперативний, усі пацієнти були піддані хірургічному лікуванню. У кожного з них під час тромбектомії була виявлена різної площі ділянка фіксації до стінки НПВ, а сам тромб повністю оклюзував НПВ за ІІ чи III рівнями. Завершальним етапом кожної тромбектомії було виконання неповної апаратної каваплікації. Ми вважаємо, що тромби, які фіксовані до стінки НПВ, є потенційно емболонебезпечними після їх видалення, оскільки залишається анатомічно скомпрометована стінка судини, яка може слугувати джерелом ембола в післяопераційному періоді. Тому незважаючи на домінуюче зниження функції здорової нирки в доопераційному періоді, ми завершали операцію неповною апаратною каваплікацією, яка накладена вище ниркових вен. Дана маніпуляція не приводить до порушення функції нирки в післяопераційному періоді.

Як приклад, наводимо клінічне спостереження за пацієнтом Л., 1955 р. н. Хворий госпіталізований в клініку зі скаргами на виражену загальну слабість, тупий біль у правій поперековій ділянці. Вважає себе хворим близько 2 міс., коли з'явилися вищенаведені скарги. Лабораторні дослідження крові до операції: гемоглобін - 103 г/л; еритроцити $3,8 \times 10^{12} /$ л; лейкоцити - $3,1 \times 10^{9} /$ л; ШОЕ - 19 мм/год; цукор крові - 5,2 ммоль/л; загальний білок - 84,4 г/л; загальний білірубін - 11,0 мкмоль/л; креатинін 189,71 мкмоль/л; сечовина - 8,38 ммоль/л; інші показники в межах норми. За даними ультразвукового дослідження, печінка помірно збільшена, дифузно ущільнена, без будь-яких вогнищевих утворів. Жовчовивідні протоки не розширені. Права нирка розміром 124×20 мм, паренхіма ущільнена розміром 19 мм, чашечки підкреслені розміром 5 мм, ниркова миска розширена до 20 мм. У середній третині нирки візуалізується солідний неоднорідної ехогенності утвір розміром $55 \times 61$ мм, який виходить за контур правої нирки. Нижня порожниста вена - 24-27 мм, містить неоднорідної ехогенності тромб розміром $38 \times 74$ мм, який піднімається в запечінковий простір НПВ. Доплерографічно виявлено зниження лінійної швидкості руху крові в НПВ до $1,5 \mathrm{~cm} / \mathrm{c}$. Ліва нирка розміром $114 \times 52$ мм, паренхіма середньої ехогенності розміром 18 мм, збиральна система не розширена. За даними МСКТ, виявлено об'ємний утвір правої нирки розміром 53х64 мм, який локалізується в середній третині нирки і виходить за ії̈ зовнішній контур; у НПВ тромб розміром $38 \times 78$ мм, який розповсюджується від рівня ниркових до рівня печінкових вен; печінка без вогнищевих утворів; парааортальні та паракавальні лімфатичні вузли не візуалізуються; надниркова залоза не збільшена. Дані динамічної реносцинтиграфії представлені на рисунку 1.

Хворому проведено хірургічне лікування: лапаротомія із трансабдомінального двобічного підребрового доступу в модифікації за типом "Chevron", правобічна нефректомія, тромбектомія із НПВ (рис. 2), неповна апаратна каваплікація вище ниркових вен. Будь-яких ускладнень під час операції та в післяопераційному періоді не було. Лабораторні дослідження крові на 5-ту добу після операції: гемоглобін - 94 г/л; еритроцити - 3,3×1012/л; лейкоцити 3,6х109/л; ШОЕ - 36 мм/год; цукор крові - 4,2 ммоль/л; загальний білок - 70,8 г/л; загальний білірубін 8,0 мкмоль/л; креатинін - 160,24 мкмоль/л; сечови- 
Закарпатський обласний клінічний онкологічний диспансер

Клінічне дослідження: Динамічна реносцинтиграфія 3 Тс99м-ДТПА

Ім'я паціснта: Л.

Номер дослідження: стать;

навантаження 4,6 м3в
Дата народження: 1955;

Ізотоп: Тс99м;
Дата дослідження: 06-12-12;

Активність (доза):; Променева

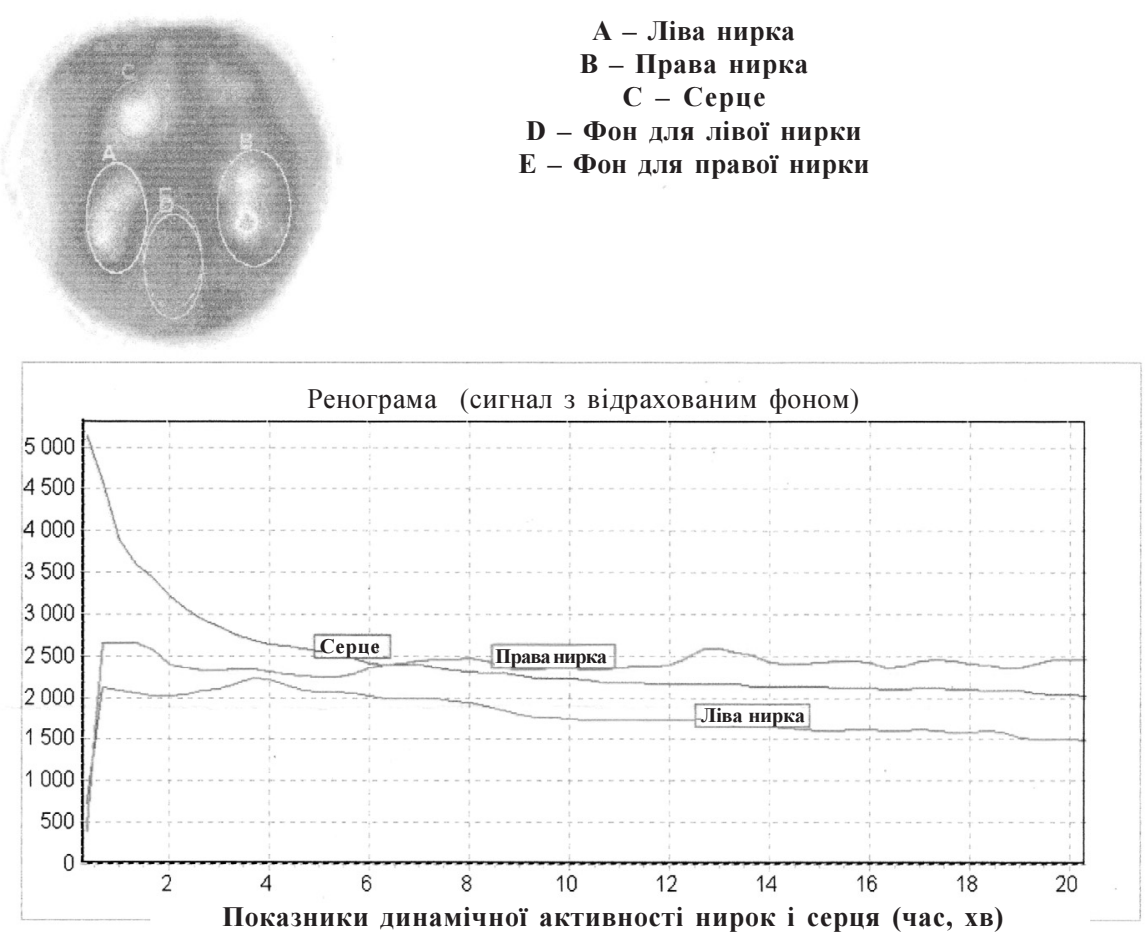

Рис. 1. Динамічна реносцинтиграфія хворого Л., 58 років. Права нирка збільшена в розмірах, деформована, накопичення радіофармпрепарату вогнищеве. Ліва нирка без змін. Видільна функція обох нирок порушена (ШКФ лівої нирки 17,20 мл/хв, правої-19,01 мл/хв), крива виведення - ізостенурична.

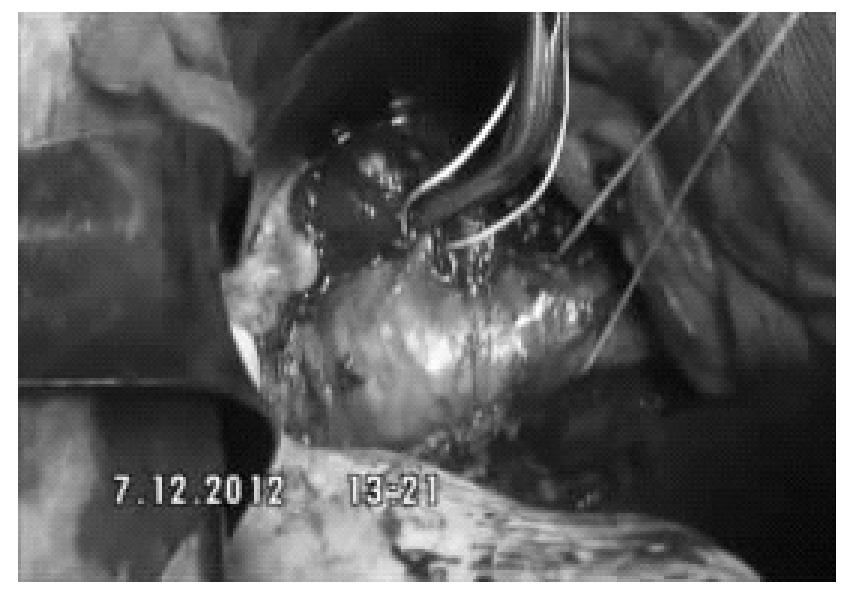

A

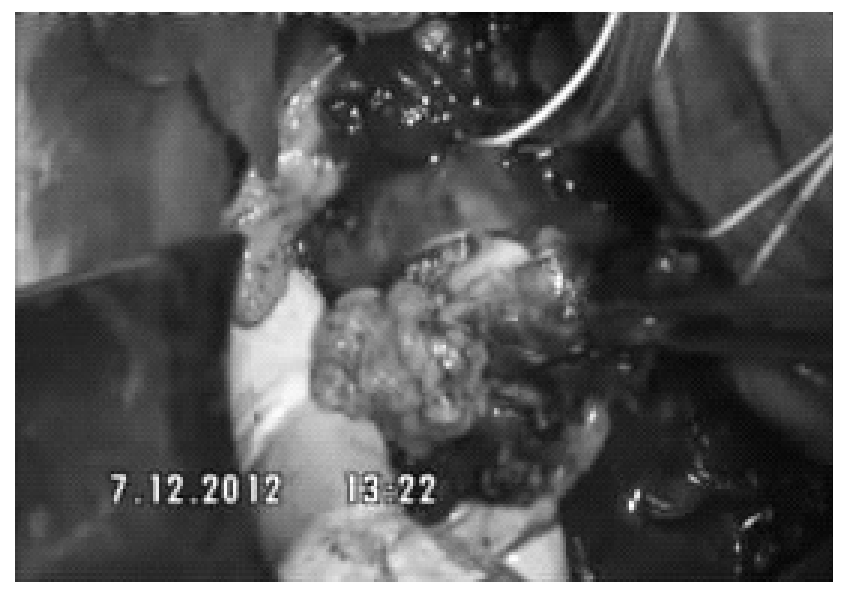

Б

Рис. 2. Інтраопераційне фото. Етап мобілізації НПВ із наступною каватомією та тромбектомією. А-інтраренальний відділ НПВ, розришений оклюзуючим тромбом, який розповсюджується в проксимальному напрямку. На НПВ і ліву ниркову вену накладено турнікети. Б- каватомія над нирковими венами, виділення тромбу через ділянку розтину.

на - 8,62 ммоль/л; інші показники в межах норми. Дані гістологічного дослідження: світлоклітинний НКР, що проростає фіброзну капсулу нирки і паранефральну клітковину, G3, раковий ембол, у просвіті ниркової вени раковий ембол, у просвіті ниркової ар- терії еритроцитарний тромб, перифокально довкола судин нирки розростання НКР. Через 10 днів після операції виконано УЗД дослідження НПВ із доплерографією: до рівня каваплікації діаметр НПВ 22 мм, лінійна швидкість руху крові - 26,9см/с; вище 
рівня плікації діаметр НПВ - 18 мм, лінійна швидкість руху крові $-17,2$ см/с. Через 1 міс. після операції виконано динамічну нефросцинтиграфію: ШКФ лівої нирки - 49,2 мл/хв, крива лівої нирки майже наблизилась до серцевої кривої.

Вже доведеним $є$ факт зниження клубочкової фільтрації у пацієнтів, яким виконано радикальну нефректомію $[2,5]$. Але в доступній нам літературі ми не знайшли описання випадків, коли більш значним було зниження функції здорової нирки, ніж ураженої пухлиною при венозній інвазії.

Таким чином, методи радіоізотопної реносцинтиграфії є простими у виконанні, майже не мають протипоказань і ускладнень, що робить їх зручни-

\section{СПИСОК ЛІТЕРАТУРИ}

1. Рак в Україні, 2010-2011: захворюваність, смертність, показники діяльності онкологічної служби. 3Н нирки [Електронний ресурс] // Бюлетень Національного канцер-реєстру. 2012. - № 13. - Режим доступу до бюлетеня: http:// www.ucr.gs.com.ua/dovidb0/PDF/0_20_poch.pdf.

2. Функция почек при почечно-клеточном раке / Э. А. Стаховський, О. А. Войленко, Ю. В. Витрук [и др.] // ОНКО2012. Протиріччя в онкоурології: науково-практ. конф. 3 міжнар. участю, 19-20 жовтня 2012 р. : тези доповідей. - Одеca, 2012. - C. 34-35.

3. Blute M. L. The Mayo Clinic experience with surgical ми й інформативними при застосуванні у пацієнтів із нирковою недостатністю різного генезу.

Висновки. У хворих на НКР, ускладнений II, III і IV рівнями венозної інвазії, може відбуватися значне зниження функції контралатеральної нирки порівняно з ураженою ниркою, що не є протипоказанням до нефректомії та тромбектомії із НПВ.

Перспективи подальших досліджень. Перспективним $є$ більш детальне вивчення впливу різних рівнів венозного тромбозу на функцію контралатеральної нирки в доопераційному та післяопераційному періодах.

management, complications and outcome for patients with renal cell carcinoma and venous tumour thrombus / M. L. Blute, D. C. Leibovich, C. M. Lohse // BJU International. - 2004. Vol. 94, № 1. - P. 33-41.

4. Epidemiologic and socioeconomic burden of metastatic renal cell carcinoma (mRCC): a literature review / K. Gupta, J. D. Miller, J. Z. Li [et al.] // Cancer Treat. Rev. - 2008. - Vol. 34. - P. 193205.

5. Estimation and prediction of renal function in patients with renal tumor / H. L. Kim, S. K. Shah, W. Tan [et al.] // J. Urol. 2009. - Vol. 181. - P. 2451-2461. 